\title{
PAPILIO HECUBA.
}

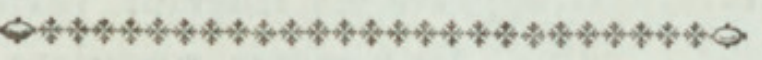

CHARACTER GENERICUS.

Antenna apicem verfus craffiores, fæpius clavatocapitatæ.

Ala (fedentis) erectæ furfumque conniventes, (volatu diurno.)

$$
\text { Lin. Syf. Nat. p. } 744 \text {. }
$$

Character Specificus, छ̈c.

PAPILIO alis anterioribus rubris, pofterioribus nigris, omnibus fubtus ocellatis.

PAPILIO alis anterioribus rubris, pofterioribus nigris, fubtus utrinque ocellatis.

$$
\text { Lin. Syft. Nat. Gmel. p. } 2247 .
$$

PAPILIO alis dentatis, anticis rubris, porticis nigris, fubtus utrinque ocellatis.

$$
\text { Lin. Mant. } 1534 .
$$

Colorum difpofitione infignis Papilio Hecuba inter maximos et lautifimos fui generis locum fibi vindicat. Alæ fuperiores læte ferrugineo-rubræ, oris fufcis; inferiores atræ longe minus nigrant juxta bafin feu ad humeros. Alarum tum fuperiorum L

tum 
tum inferiorum margines decorat feries macularum leviter flaventium. Corpus grifeum, feu canefcens. Alarum omnium fuperficies inferior variis umbris nigris, fufcis, canis, ferrugineis undulata, maculis quoque quafi ocellatis concoloribus adornatur. Americam Auftralem incolit venuftiffima hæc fpecies. 



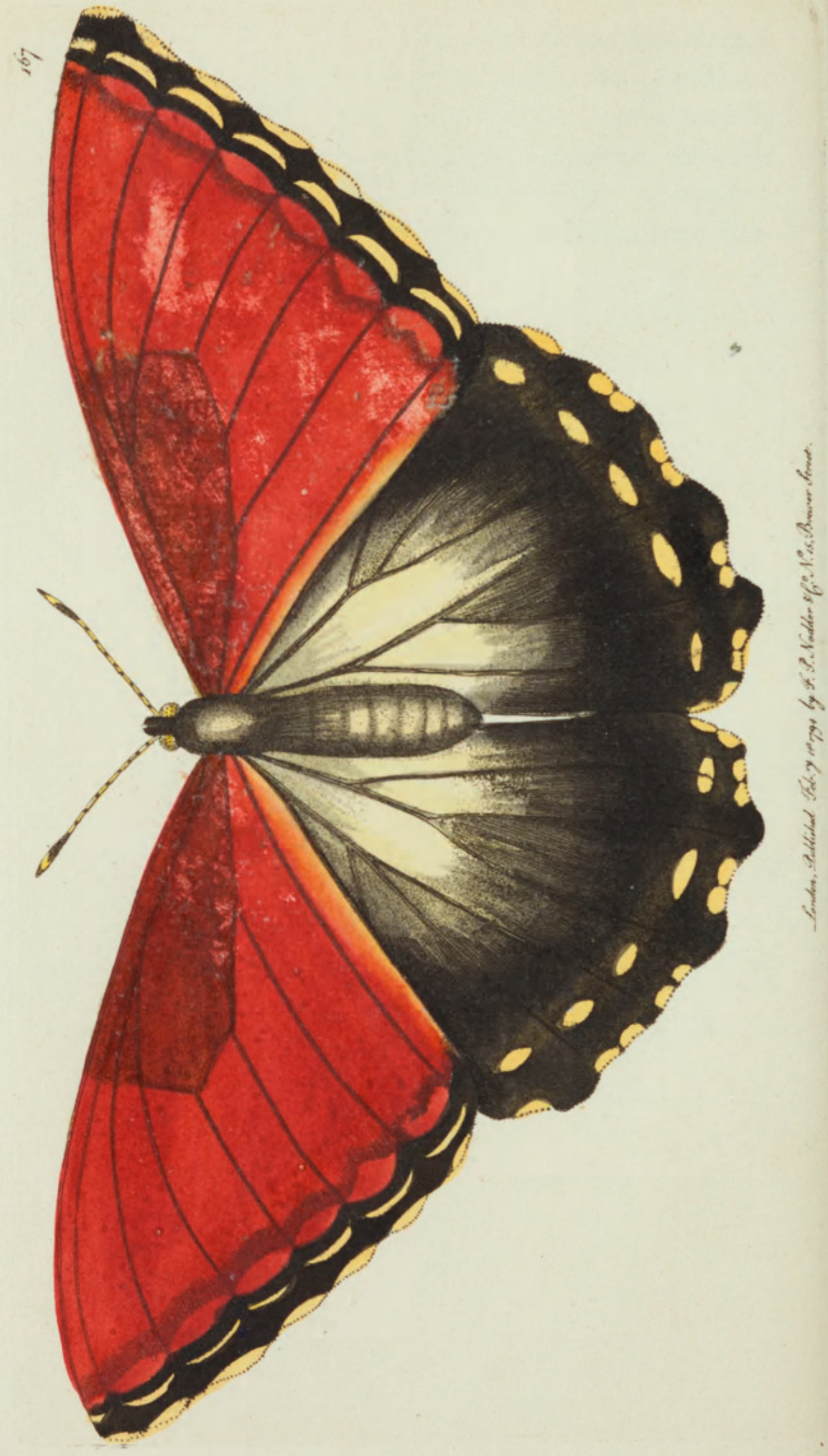




\section{H E C U B A.}

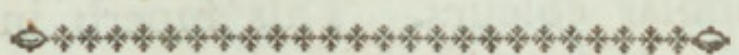

\section{GENERIC CHARACTER.}

Antenne or Horns thickening towards the upper part, and generally terminating in a knob, or club-fhaped tip.

Wings (when fitting) erect, and meeting upwards. (Flight diurnal.)

SPECIFIC CHARACTER, ËC. BUTTERFLY with the upper wings red, the lower black; each pair ocellated beneath.

\section{LE GRAND OCULÉ DE CAYENNE.}

$$
\text { Pl.enl. } 19 .
$$

The Papilio Hecuba is one of the largeft and moft magnificent of its tribe. It is alfo remarkable for the fingularity of its colour; the upper wings being of a very rich ferruginous-red with dufky edges, while the lower ones are black, but confiderably paler towards their bafe than on the broader part. Both the upper and lower wings are edged with a feries of palifh yellow fpots. The body is greyilh. The under furface of all the wings is undulated 
dulated with various fhades of brown, black, grey, and ferruginous, and marked by feveral eye-like fpots of fimilar colours. This fuperb infect is a native of South America. 


\section{$2 \mathrm{BHL}$ Biodiversity Heritage Library}

Shaw, George. 1794. "Hecuba, Papilio hecuba [PI. 167]." The Naturalist's Miscellany 5(LV), https://doi.org/10.5962/p.310746.

View This Item Online: https://www.biodiversitylibrary.org/item/276340

DOI: https://doi.org/10.5962/p.310746

Permalink: https://www.biodiversitylibrary.org/partpdf/310746

\section{Holding Institution}

Museums Victoria

\section{Sponsored by}

Atlas of Living Australia

\section{Copyright \& Reuse}

Copyright Status: Public domain. The BHL considers that this work is no longer under copyright protection.

This document was created from content at the Biodiversity Heritage Library, the world's largest open access digital library for biodiversity literature and archives. Visit BHL at https://www.biodiversitylibrary.org. 